\title{
Interview with Dr. Janet Landeen / Entrevue avec la Dre Janet Landeen
}

Jacinthe I. Pepin

Université de Montréal, jacinthe.pepin@umontreal.ca

Florence Myrick

amyrick@ualberta.ca

Follow this and additional works at: https://qane-afi.casn.ca/journal

Part of the Nursing Commons, and the Scholarship of Teaching and Learning Commons

\section{Recommended Citation}

Pepin, Jacinthe I. and Myrick, Florence (2016) "Interview with Dr. Janet Landeen / Entrevue avec la Dre Janet Landeen," Quality Advancement in Nursing Education - Avancées en formation infirmière: Vol. 2: Iss. 1, Article 7. DOI: https://doi.org/10.17483/2368-6669.1081

This Interview is brought to you for free and open access by Quality Advancement in Nursing Education - Avancées en formation infirmière. It has been accepted for inclusion in Quality Advancement in Nursing Education - Avancées en formation infirmière by an authorized editor of Quality Advancement in Nursing Education - Avancées en formation infirmière. 


\section{Interview with Dr. Janet Landeen 2015 Ethel Johns' award recipient}

Interviewee: Dr. Janet Landeen, Associate Professor, School of Nursing, McMaster University, Hamilton, $O N$

Interviewer: Dr. Jacinthe Pepin, Co-Editor in Chief

Dr. Pepin: Before we begin, I would like to congratulate you, on behalf of Dr. Florence Myrick and myself, for receiving the most prestigious Canadian Association of Schools of Nursing (CASN)'s award, the Ethel Johns award.

Dr. Pepin: Let's start with this award that you received in 2015. What does it mean to you as Associate Professor and nursing education researcher?

Dr. Landeen: I was truly humbled and honored to have received this award. It felt like a life-time achievement and really a pinnacle of my career. It was a recognition of the importance of nursing education research. For many of my colleagues, within the school and within other departments at the university, we know that clinical research or health content-specific research is valued more highly than educational research. Yet, I have chosen nursing education research as part of what I've done with my career, and this award was really recognition and a reaffirmation that this is important.

Dr. Pepin: You have been an Assistant Dean of the Undergraduate Nursing Education Program at McMaster University from 2004 to 2012. What would you identify as being the major areas that are most in need of nursing education knowledge production and its application in the present time?

Dr. Landeen: I think that the main need for knowledge is actually the same as it has been for quite some time. If you go back to Bevis and Watson's (1989) publication - A New Pedagogy for Nursing, and also Benner, Sutphen, Leonard and Day's (2010) publication on transforming nursing

\section{Entrevue avec la $D^{\text {re }}$ Janet Landeen*}

\section{Récipiendaire du prix Ethel Johns 2015}

Invitée : $D^{r e}$ Janet Landeen, professeure agrégée, École de sciences infirmières, McMaster University, Hamilton, $\mathrm{ON}$

Intervieweuse : $D^{r e}$ Jacinthe Pepin, corédactrice en chef

$D^{\text {re }}$ Pepin : Avant de commencer, je me joins à la $\mathrm{D}^{\text {re }}$ Florence Myrick pour vous féliciter d'avoir obtenu le prix le plus prestigieux de l'Association canadienne des écoles de sciences infirmières (ACESI), le prix Ethel Johns.

$D^{\text {re }}$ Pepin : Commençons par discuter de ce prix qui vous a été décerné en 2015. Qu'est-ce que cela représente pour vous en tant que professeure agrégée et chercheuse en formation en sciences infirmières?

$D^{\text {re }}$ Landeen : J'ai été réellement touchée et honorée de recevoir ce prix. C'est l'accomplissement de toute une vie, le point culminant de ma carrière, visant à reconnaître l'importance de la recherche en formation en sciences infirmières. Plusieurs de mes collègues, à l'école des sciences infirmières et dans d'autres départements de l'université, savent que la recherche clinique ou la recherche sur des sujets spécifiques en santé sont considérées comme plus importantes que la recherche en éducation. J'ai tout de même choisi d'inclure la recherche en formation en sciences infirmières à mes activités professionnelles, et ce prix était une reconnaissance ainsi qu'une confirmation de l'importance de ce domaine de recherche.

$D^{\text {re }}$ Pepin : De 2004 à 2012, vous avez été vicedoyenne du programme d'études de premier cycle en sciences infirmières à McMaster University. Selon vous, quels sont les domaines ayant le plus besoin de développement et d'application immédiate de nouvelles connaissances pédagogiques?

$D^{\text {re }}$ Landeen : Je crois que le principal besoin en matière de connaissances est le même depuis un certain temps. Si vous pensez à la publication de

\footnotetext{
* Dans le but d'alléger le texte, les termes au féminin comprennent le masculin.
} 
education - A Call for Radical Transformation these authors are all calling for the same thing. Nursing educators help students transform into nurses whom they think the population wants and needs: nurses who are knowledge-based and also caring, and who are committed to the profession. I don't think this is in any way a new goal. In fact, Barnett (2009) has written about this in Knowing and becoming in the higher education curriculum in relation to postsecondary education in general. We are currently seeing some educational research about flipped classrooms or other pedagogical methods, as if these were something new.

The questions are: How do we, as educators, actually put into practice, and in particular help our new faculty members learn how to engage students in deep learning? Not just learning for the test, but to truly learn what it means to be a knowledge-based professional and also a caring professional, with all of the different ways of knowing. How do we help our nursing faculty implement the health professional education knowledge that we know should be happening into classrooms?

Dr. Pepin: Would you have any suggestions as to how we can best address this issue with research questions?

Dr. Landeen: We need to do research on how to implement evidence-based education. There is a great deal of evidence about the more effective ways of doing education. I think there is also evidence on the fact that it may take five years for even mandated, legislated changes in educational practice to be implemented.

Moreover, our educational systems now hire more and more part-time faculty, who may or may not have that solid grounding in an educational background. One of the advantages some nursing educators have had is kind of paradoxical. Certainly, for me and colleagues of my age, when we did our masters, we did not have the option to do a Masters in Nursing; there weren't any easily available to us at the time. So, we chose to do a Master's in Education. It's wonderful that we now have Masters in Nursing and Doctorates in Nursing, but we need to ensure that our graduate programs also have some content around education.

So, I think it would be great to do some research around new faculty members, and what helps them to
Bevis et Watson (1989), A New Pedagogy for Nursing, ainsi qu'à celle de Benner, Sutphen, Leonard et Day (2010) sur la transformation de la formation en sciences infirmières, A Call for Radical Transformation, ces auteures décrivent toutes la même chose. Les formatrices en sciences infirmières aident les étudiantes à devenir les professionnelles dont la population, selon elles, a besoin : des infirmières qui fondent leur pratique sur des savoirs, mais aussi qui démontrent du caring et qui sont engagées envers leur profession. Je ne vois pas en quoi cela constitue un nouvel objectif. En fait, Barnett (2009), dans Knowing and becoming in the higher education curriculum, a écrit sur ce sujet dans le contexte général de l'éducation postsecondaire. Des recherches sont actuellement menées sur les classes inversées ou d'autres méthodes pédagogiques, comme si elles étaient nouvelles.

La vraie question est : Comment, en tant que formatrices, allons-nous mettre ces méthodes en pratique? Plus particulièrement, comment allonsnous aider les nouveaux membres du corps professoral à apprendre à promouvoir l'apprentissage en profondeur auprès de leurs étudiantes? Il ne s'agit pas seulement de tout apprendre pour réussir aux examens, mais d'apprendre ce que cela veut dire être une professionnelle qui a des connaissances et qui démontre du caring, tout en utilisant les divers modes de savoir. Comment aidons-nous le corps professoral en sciences infirmières à intégrer les connaissances issues de la pédagogie des professions en santé, qui devraient être en œuvre dans les classes?

$D^{\text {re }}$ Pepin : Avez-vous des suggestions pour examiner cette problématique grâce à la recherche?

$D^{\text {re }}$ Landeen : Nous devons faire des recherches pour savoir comment mettre en œuvre un enseignement basé sur les meilleures pratiques. Il existe de nombreux résultats de recherche concernant les méthodes pédagogiques les plus efficaces, mais il a aussi été démontré que l'implantation d'un changement pédagogique même prescrit et légiféré peut prendre jusqu'à cinq ans.

De plus, notre système d'éducation supérieure actuel favorise de plus en plus l'embauche de personnels enseignants à temps partiel, qui n'ont pas toujours un bagage solide en pratiques pédagogiques. L'un des avantages dont ont pu bénéficier certaines professeures en sciences infirmières est plutôt paradoxal. Par exemple, lorsque mes collègues et moi 
become evidence-based educators. We should research the impact of activities on pedagogy offered by the university to new faculty members, as well as mentorship to help promote evidence-based teaching. I also think there are research questions around the timing of those activities. In the first year or so, implementing these activities for new faculty probably isn't as effective because the person is overwhelmed with content. But by the second year or the third year of being a teacher, I think that is the time to be doing interventions. So I would love to see some intervention studies around how we can help people become better evidence-informed teachers, academics.

Dr. Pepin: What are your suggestions or recommendations for new faculty members as far as evidence-based nursing education is concerned?

Dr. Landeen: For them, I would suggest that they attend CASN conferences and other educational conferences. Nursing is privileged to have many nursing education journals and conferences, more so than professions outside of the health disciplines. Firstly, they should be made aware of these journals and conferences and secondly, they should be provided with mentors. Those mentors could be from anywhere across the country.

Dr. Pepin: Can you tell us more about this perspective?

Dr. Landeen: For example, I am currently the mentor of someone who just started teaching. Her classroom is next to mine. So, it facilitates conversations during breaks, about how things are going on in class or if she has any questions. I am making myself available to her without overwhelming her with "you should read this".

At the same time, it would be so much fun to form some country-wide mentorship programs. I think we become too institutionally-bound. Sometimes we are too competitive and not focused enough on sharing ideas. I know that my best research ideas occur when I am in conversations with people who have totally different backgrounds or experiences than I have. I learn what they are doing, which in turn prompts me to read in a whole different area, one that I would not have considered previously.

Dr. Pepin: Your own research areas in nursing education encompass the evaluation of nursing curricula design and implementation. As well, you avons entrepris notre maîtrise, nous n'avions pas la possibilité de la faire en sciences infirmières. Il nous était difficile d'y avoir accès à l'époque; nous avons donc opté pour une maîtrise en sciences de l'éducation. C'est formidable que nous ayons aujourd'hui des maîtrises et des doctorats en sciences infirmières, mais nous devons nous assurer que nos programmes d'études supérieures permettent aussi de développer des compétences en formation.

Je crois donc qu'il serait important de se pencher sur les nouveaux membres du corps professoral, sur ce qui les aiderait à enseigner selon les meilleures pratiques pédagogiques et les résultats probants. Nous devrions examiner les effets des activités de développement pédagogique offertes par les universités, ainsi que la mise en place de programmes de mentorat auprès des nouveaux enseignants, qui visent à promouvoir l'enseignement basé sur les meilleures pratiques. Je crois aussi qu'il faut considérer le moment où se déroulent ces activités de soutien. Lors de la première année d'enseignement, l'offre de ces activités pour les nouveaux membres du corps professoral n'est probablement pas aussi efficace, car ils sont souvent submergés par le contenu à enseigner. Selon moi, il serait mieux de soutenir le développement pédagogique pendant la deuxième ou la troisième année d'enseignement. J'aimerais beaucoup voir des études d'intervention portant sur la façon d'aider les personnes à devenir de meilleures professeures ou universitaires, qui appuient leur enseignement sur les meilleures pratiques.

$D^{\text {re }}$ Pepin : Quelles sont vos suggestions ou recommandations pour les nouveaux membres du corps professoral concernant la formation en sciences infirmières basée sur les meilleures pratiques pédagogiques?

$D^{\text {re }}$ Landeen : Je leur suggèrerais de participer à des conférences de l'ACESI ou à d'autres conférences sur la pédagogie dans le domaine de la santé. Nous avons la chance en sciences infirmières de bénéficier de plusieurs conférences et revues scientifiques sur ce sujet, plus encore que les professions des domaines non reliés à la santé. Les nouveaux professeurs devraient d'abord être informés de l'existence de ces revues et conférences, puis recevoir l'appui d'un mentor, de n'importe où au pays. 
have been designing, implementing, and conducting research on different aspects of problem-based learning. What do you envision for nursing and health professionals with regard to this approach or with different learning approaches?

Dr. Landeen: Whenever you are making a curriculum change, there is the opportunity to carry out some research: either you are engaging in a curriculum redesign or modification based on research, and then, when you implement the change, you proceed with a formal evaluation. It is more than just a program evaluation, inasmuch as you want to know which of these ideas were actually useful and which were not. I believe that this process is something important, and that you should build it in right from the beginning.

I have a manuscript currently in revision in which we are evaluating the student experience from four different programs within university-college partnerships. We are looking to publish it outside of health education journals, in the Canadian Journal of Higher Education. Looking at how things are achieved across programs, even within an institution might be of interest to readers. Going beyond the evaluation of one program and being able to compare is actually more rigorous research and it provides you with different insights.

As far as problem-based learning is concerned, when you think back, it originated in the medical school here at McMaster University. In the original writing, the focus of all the learning problems was on striving to understand the conundrum of differential diagnoses and treatment approaches. These are medical questions. For nursing, there is another question. We have redesigned problem-based learning here at the School of Nursing to be personbased learning within a problem-based approach. We thus place the person at the center of learning nursing and facilitate students to think first about the person through rich multi-media narratives. What are their challenges so that nursing can be of assistance? And then they engage in the process of ascertaining what they know and what they do not know, always starting with who is the person? How are they living with illness? That is really the nursing focus: the person living with illness, preventing illness, promoting health. It is also about community. Hence, we have modified problem-based learning so that it is more nursing oriented.
$D^{\text {re }}$ Pepin : Pouvez-vous nous en dire davantage à ce sujet?

$D^{\text {re }}$ Landeen : Par exemple, en ce moment, je suis la mentor d'une personne qui vient de commencer à enseigner. Puisque sa classe est à côté de la mienne, nous pouvons échanger pendant les pauses (p. ex., sur la façon dont les choses se déroulent en classe) et je peux répondre à ses questions. Je me rends disponible pour elle sans la submerger de recommandations de lecture.

En même temps, il serait stimulant de créer des échanges entre programmes de mentorat au pays. Je crois que nous devenons trop liés à nos établissements d'enseignement. Il nous arrive d'être trop compétitifs et de ne pas nous centrer sur le partage d'idées. Je sais que mes meilleures idées de recherche me sont venues lors de conversations avec des personnes provenant de milieux complètement différents du mien et ayant vécu d'autres expériences. J'apprends ce qu'elles font, ce qui me pousse à lire au sujet d'un domaine très différent auquel je n'aurais probablement jamais pensé.

$D^{\text {re }}$ Pepin : Vos propres domaines de recherche en sciences infirmières comprennent l'évaluation de la structure et de la mise en œuvre de programmes d'études en sciences infirmières. Vous avez aussi dirigé des recherches sur différents aspects de l'apprentissage par problèmes. Quelle est votre vision de l'apprentissage par des professionnelles des sciences infirmières et de la santé concernant cette approche ou des approches différentes?

$D^{\text {re }}$ Landeen : Chaque modification d'un programme d'études constitue une occasion de mener des recherches; qu'il s'agisse d'une refonte de programme ou d'une révision basée sur la recherche; une évaluation formelle peut suivre la mise en œuvre du changement. C'est plus qu'une simple évaluation du programme, dans la mesure où vous voulez savoir quelles idées ont réellement été utiles et lesquelles ne l'ont pas été. Je crois que ce processus est important, et qu'il doit être élaboré et amorcé dès le départ.

J'ai soumis un manuscrit qui est en révision dans lequel nous évaluons l'expérience d'étudiantes de quatre programmes différents dans le cadre de partenariats entre universités et collèges. Nous cherchons à le faire publier dans une revue qui n'est pas du domaine de la formation en santé, plus précisément dans la Canadian Journal of Higher 
Problem-based learning is an approach that gives students a set of abilities to help them determine what they do not know, how to find that information, how to evaluate the quality of that information, how to actually own that information, and how to apply it. The process is very useful, but it can also be repetitive. As students are graduating, they have the abilities but what they do not necessarily have is how to shift that process to think in terms of a larger system's issue (instead of a patient problem). We have started a pilot project, in our final course, to help the students make this shift and to develop the skills that they can bring to their work setting and become leaders in thinking about changes in systems. I have taught four classes that way. So far, I have just received informal student feedback. I am waiting for the first written evaluations and deciding whether we can formalize this process.

Dr. Pepin: So, what I am hearing you say is that developing the ability to understand the persons and the larger systems should facilitate the process of preparing change agents who participate in the transformation of health systems. Do you think that the problem-based learning approach will remain strong within nursing curricula while evolving towards the person and the system?

Dr. Landeen: Yes, and also at McMaster, when I first started teaching in the late $80 \mathrm{~s}, 1$ had eight students in the class. We are now working with up to 40 students. You cannot be truly student-centered with 40:1, you need to use active learning strategies, such as dividing people into smaller groups and reconvening them back into larger groups. There are all kinds of creative ways of actively engaging students in the class. Active engagement is a key idea in learning.

Another key point with problem-based learning or any active learning is that to a novice teacher, it may appear easier on the surface, because you do not have to stand up and lecture about the content. But, actually, to be an excellent teacher who facilitates learning and knows how to draw knowledge out of the students, rather than giving it, actually requires a higher level skill.

Dr. Pepin: Today, we engage with diverse students some of whom have been taught in a more traditional way prior to arriving in the nursing programs. How would you suggest we foster this climate for
Education (Revue canadienne d'enseignement supérieur). Les lecteurs pourraient être intéressés à connaître diverses façons de fonctionner au sein de différents programmes, et même au sein d'un même établissement. Aller au-delà de l'évaluation d'un programme et être en mesure de comparer, c'est effectuer des recherches plus rigoureuses qui permettent d'avoir accès à des perspectives différentes.

En ce qui concerne l'approche de l'apprentissage par problèmes, on se souvient qu'elle a été développée ici, par la Faculté de médecine de McMaster University. Dans la méthode originale, chercher à comprendre l'énigme des diagnostics différentiels et des approches thérapeutiques était au cœur de tous les problèmes d'apprentissage. Ces questions sont propres au domaine médical. Pour les sciences infirmières, il y a une autre dimension. Nous avons repensé l'apprentissage par problèmes, à l'école de sciences infirmières, pour le transformer en un apprentissage centré sur la personne, dans le cadre d'une approche par problèmes. Nous plaçons donc la personne au centre de la formation infirmière et aidons les étudiantes à travers de riches récits multimédias à penser à la personne d'abord. Quelles difficultés vivent-elles et pour lesquelles les sciences infirmières peuvent être utiles?? Les étudiantes évaluent ensuite ce qu'elles savent et ce qu'elles ont besoin d'apprendre, en commençant toujours par la question: Qui est la personne? Comment vit-elle avec la maladie? C'est vraiment sur quoi nous mettons l'accent en sciences infirmières : la personne aux prises avec la maladie, la prévention de la maladie, la promotion de la santé. Il y a aussi la communauté. Nous avons donc revu l'approche d'apprentissage par problèmes pour qu'elle soit mieux adaptée aux sciences infirmières.

L'apprentissage par problèmes est une approche qui donne aux étudiantes un ensemble de ressources internes pour les aider à déterminer ce qu'elles ne savent pas, comment trouver et évaluer la qualité de cette information manquante, comment réellement s'approprier et mettre en application cette information. . Bien que très utile, cette méthode peut aussi être répétitive. À la fin de leurs études, les étudiantes comprennent les processus, mais ne savent pas nécessairement comment les transposer dans le cadre d'une situation concernant un système plus vaste (plutôt qu'une situation concernant un patient). Dans notre dernier cours, nous menons un projet 
engaging in learning, this motivation?

Dr. Landeen: It is about inspiring the excitement about learning and helping students turn onto the excitement of actually uncovering something. I remember a student talking to me about how she was so uncomfortable with this style of learning: prior to this program, she had only stood at her desk when called upon to answer a question; she would respond in as few words as possible, and then sit down. Thus, this approach was so much an opposite for her. As a teacher, it is important to learn how to be supportive, and in fact use many of your clinical skills in order to facilitate growth in students.

Dr. Pepin: Many decision-making bodies are urging for more interprofessional heath education. From your perspective, what do you perceive as the future of nursing education programs and of nursing education research programs?

Dr. Landeen: I absolutely think that we need to be doing better at interprofessional health education. Since we work together as interprofessional teams, the best way to learn about each other's professions and develop mutual respect, is to learn with each other, from each other and about each other, but not merely by sitting side-by-side in a classroom without ever interacting.

In order for nursing to engage in that interactive learning, nursing students have to possess a strong identity of who they are. One of my doctoral students, Dr. Susan Anthony, completed her thesis on nursing's engagement in interprofessional education, exploring the prerequisites for nurses to be able to engage. She conducted a case-study across three different universities. What she found from her study was that nurses wanted to be engaged, but that in addition to needing the time to engage, a primary challenge was that they were still unsure about who they were as nurses, and they felt the need to protect their identity. One of the challenges of being in an interprofessional setting is being able to talk about what nurses are actually doing, what their contribution to patients' health is since nursing is not simply filling in the spaces.

Dr. Pepin: For future nursing education programs then, is it fair to say that you see the need to integrate more interprofessional activities that would engage students working together from a clearer professional identity. pilote pour aider les étudiantes à faire cette transition et à développer des habilités dont elles auront besoin dans leur environnement de travail, afin de devenir des leaders qui provoquent des changements dans les systèmes. J'ai enseigné à quatre groupes d'étudiantes de cette façon. Pour l'instant je n'ai reçu que des rétroactions informelles de la part des étudiantes. J'attends les premières évaluations écrites, qui nous permettront de déterminer si ce processus peut être implanté formellement.

$D^{\text {re }}$ Pepin : Donc, si je comprends bien ce que vous dites, le développement de la capacité des étudiantes à comprendre les personnes et les systèmes plus vastes devrait faciliter la préparation d'agentes de changement qui participeront à la transformation des systèmes de santé. Pensez-vous que l'approche de l'apprentissage par problèmes, en évoluant vers la personne et le système, restera tout de même bien ancrée dans les programmes de sciences infirmières?

$D^{\text {re }}$ Landeen : Oui. Et je peux vous dire qu'à mes débuts comme enseignante à McMaster, à la fin des années 80, il n'y avait que huit étudiantes par groupe. Aujourd'hui, les groupes peuvent compter jusqu'à 40 étudiantes. Comme il s'avère difficile d'être véritablement centrée sur les étudiantes dans de tels cas, des stratégies d'apprentissage actives, comme diviser les étudiantes en petits groupes et les réunir à nouveau dans de grands groupes, doivent être utilisées. La participation active des étudiantes est une notion clé de l'apprentissage, et il y a toutes sortes de façons créatives de faire participer activement les étudiantes.

Un autre point important de l'apprentissage par problèmes ou tout autre mode d'apprentissage actif est qu'il peut sembler à première vue plus facile pour une enseignante débutante, parce qu'il n'exige pas de donner un cours magistral devant un groupe d'étudiantes sur un sujet donné. Cependant, une enseignante doit en réalité être hautement compétente pour faciliter l'apprentissage et permettre aux étudiantes de s'approprier des connaissances au lieu de tout simplement les « recevoir ».

$D^{\text {re }}$ Pepin : Nous rencontrons aujourd'hui dans nos classes une grande diversité d'étudiantes, dont certaines qui ont reçu un enseignement plus traditionnel avant de s'inscrire dans un programme de sciences infirmières. Que suggériez-vous pour favoriser un climat motivant et propice à la 
Dr Landeen: Yes, and learning around case studies. Certainly, simulation is one of the ideal places to have students witness first hand each other's roles in one clinical situation with a patient. It is actually quite easy to engage in problem-based learning in an interprofessional setting. The challenge is always scheduling so that the appropriate level students can work together, and that such a process is built in as a core to the curriculum, rather than an add-on.

And absolutely build it in clinical areas. I still supervise clinical students in mental health settings. You cannot be an effective mental health team unless you are interprofessional. I have always practiced in interprofessional environments. In my last clinical job I set up interprofessional student rounds: I would meet with a group of psychiatric residents, medical students, occupational therapy students, social work students, and nursing students. Together we talked about how we would approach a specific patient. So it would be similar to a post-conference with an interprofessional approach.

Dr. Pepin: Are there any other thoughts you would like to share with the readers of Quality advancement in Nursing Education / Avancées en formation infirmière?

Dr. Landeen: It has been such a rewarding career. We are so privileged that we get to do what we do as nursing educators. Engaging in research makes everything more enriching. When I think about my own career: moving from the bedside, to being a middle management nursing administrator, to being a teacher, to being an administrator for a nursing education program, to conducting research. The bottom line is, it still is all about nursing. Nursing is an enriching career. At all different levels you may be directly impacting the life of an individual or you may be striving to change a system to provide better healthcare, and ensure better health. We have meaningful and interesting work.

Dr. Pepin: This is a positive message for those contemplating an academic career. Indeed, some may think that in embarking on nursing education, it may bring them too far from clinical nursing. You emphasize how meaningful and enriching nursing education and research could be.

Dr. Landeen: One of the challenges for faculty is to stay current clinically and to have direct clinical practice. In medicine they've sorted this out. For participation dans ce contexte d'apprentissage?

$D^{\text {re }}$ Landeen : Je crois qu'il faut inspirer l'enthousiasme à l'égard de l'apprentissage et susciter chez les étudiantes l'excitation de découvrir de nouvelles choses. Je me souviens d'une étudiante qui m'avait confié son malaise face à ce style d'apprentissage: avant ce programme, elle avait l'habitude de se lever de son bureau uniquement lorsqu'on lui posait une question, à laquelle elle répondait le plus brièvement possible avant de se rassoir. Ainsi, cette approche, moins traditionnelle, était diamétralement opposée à ce qu'elle avait connu jusque-là. Il est important que les enseignantes apprennent à soutenir les étudiantes, et même se servent de plusieurs compétences cliniques afin de faciliter leur épanouissement.

$D^{\text {re }}$ Pepin : De nombreuses instances font valoir l'importance du développement de la formation interprofessionnelle en santé. Comment voyez-vous personnellement l'avenir des programmes de formation en sciences infirmières et des programmes de recherche en formation infirmière?

$D^{\text {re }}$ Landeen : Je suis tout à fait d'accord qu'il est nécessaire de faire mieux en matière de formation interprofessionnelle en santé. Puisque nous travaillons ensemble au sein d'équipes interprofessionnelles, il est évident que la meilleure façon d'en apprendre davantage sur la profession de l'autre et de développer un respect mutuel est d'apprendre en compagnie de l'autre, d'apprendre l'un de l'autre et d'apprendre à mieux se connaître, mais pas seulement en étant assis côte à côte dans une salle de classe, sans jamais interagir.

Afin de prendre part à cet apprentissage interactif, les étudiantes en sciences infirmières doivent avoir une identité professionnelle forte. Une de mes étudiantes au doctorat, la $\mathrm{D}^{\text {re }}$ Susan Anthony, a soutenu sa thèse sur la participation des sciences infirmières à la formation interprofessionnelle; elle a examiné les conditions préalables à la participation des infirmières. L'étude de cas qu'elle a menée dans trois universités différentes a révélé que les infirmières désiraient participer, mais qu'en plus de manquer de temps pour le faire, elles n'étaient toujours pas solides pour s'exprimer sur leur rôle en tant qu'infirmières et elles ressentaient le besoin de protéger leur identité. L'un des défis d'évoluer dans un cadre interprofessionnel est la nécessité de s'exprimer sur le véritable travail des infirmières et 
nursing it is a huge challenge. On top of my full-time job, I could go and work a shift on a week-end. My full-time job is a very full-time job. My faculty salary is higher than it would be in a clinical setting, and so clinical settings cannot really afford to buy me out. And my university expects full time work. So, the challenge becomes how to find the time and the energy to also engage in active clinical practice and stay clinically current?

I do engage in many partnerships with clinical agencies, and have clinical students. One of the expectations of our preceptorship program is that you actually meet with final year students and their preceptors in the clinical setting, at least three times per term (at the beginning, at mid-term and at final). Through this process, you acquire a sense of what is happening in clinical practice. I am trying to stay current with the issues and the clinical practice, but that is very different from providing direct patient care.

During the first 10 years of my career with McMaster, I had a joint appointment $(50 \%$ paid by Hamilton Program for Schizophrenia and 50\% paid by the university). I was in the clinical area, assigned to students, and taught classes at the university. I had two offices in different parts of town. There were challenges at the institutional level that made it difficult; our joint appointments have disappeared because they were the easy ones to cut from the clinical sites.

I really believe in partnerships and collaboration (university-clinical milieu, university-college, between programs, between universities) and putting the competition aside. We are all in competition for funding. By its very nature, the system builds in the competition, but the meaningful work is when it's engaged in collaboratively.

Dr. Pepin: On behalf of Dr. Florence Myrick and myself, co-Editors-in-Chief, I would like to thank you for taking the time to share your knowledge, thoughts, and wisdom. sur leur contribution à la santé des patients, car les infirmières ne sont pas simplement là pour combler des vides.

$D^{\text {re }}$ Pepin : Dans ce cas, pour les futurs programmes de formation en sciences infirmières, est-il juste de dire que vous constatez la nécessité d'intégrer plus d'activités interprofessionnelles qui feraient travailler les étudiantes ensemble à partir d'une identité professionnelle mieux définie?

$D^{\text {re }}$ Landeen : Oui, et l'apprentissage autour d'études de cas est aussi nécessaire. La simulation constitue en fait l'un des meilleurs moyens pour les étudiantes de prendre conscience des rôles respectifs de chacune dans des situations cliniques avec des patients. C'est en fait assez facile d'intégrer l'apprentissage par problèmes dans un cadre interprofessionnel. Le défi demeure la planification des calendriers, pour que les étudiantes d'un niveau équivalent puissent travailler ensemble, et l'implantation d'un tel processus comme une composante centrale du programme plutôt qu'un complément.

De plus, il importe que la mise en œuvre se fasse dans des environnements cliniques. Il m'arrive encore de superviser des étudiantes en stage dans des établissements de santé mentale. Une équipe œuvrant dans ce milieu ne peut être efficace que si elle est interprofessionnelle. J'ai d'ailleurs toujours pratiqué dans des environnements interprofessionnels. Dans mon dernier emploi clinique, j'organisais des tournées interprofessionnelles avec les étudiantes : je rencontrais un groupe composé de résidentes en psychiatrie et d'étudiantes en médecine, en ergothérapie, en travail social et en sciences infirmières. Ensemble, nous parlions de la façon d'approcher différents patients. Cela ressemblait à une rencontre post-clinique avec une approche interprofessionnelle.

$D^{\text {re }}$ Pepin : Y a-t-il d'autres réflexions que vous aimeriez partager avec les lecteurs d'Avancées en formation infirmière / Quality Advancement in Nursing Education?

$D^{\text {re }}$ Landeen : J'ai eu une carrière très enrichissante. Nous sommes privilégiées de pouvoir faire ce que nous faisons en tant que professeures en sciences infirmières. Participer à la recherche rend tout plus enrichissant. Dans mon parcours professionnel, je suis passée d'infirmière au chevet à cadre intermédiaire en milieu clinique, puis j'ai été 
enseignante et directrice d'un programme de formation en sciences infirmières. Aujourd'hui je fais de la recherche. En fin de compte, tout a tourné autour des sciences infirmières, qui représentent une carrière enrichissante. Quel que soit le niveau, vous pouvez influencer directement la vie d'une personne comme vous pouvez tenter de modifier un système pour fournir de meilleurs soins et assurer une meilleure santé. Notre travail est à la fois significatif et intéressant.

$D^{\text {re }}$ Pepin : Voilà un message positif pour celles qui envisagent poursuivre une carrière académique. En effet, certaines pourraient penser que la formation en sciences infirmières est bien loin des soins infirmiers cliniques, mais vous soulignez à quel point la recherche et la formation en sciences infirmières peuvent être des volets significatifs et enrichissants dans une carrière.

$D^{\text {re }}$ Landeen : L'un des défis des membres du corps professoral est de se tenir au courant des développements cliniques et de maintenir une pratique clinique directe. En médecine, ils ont réglé ce problème. Pour les sciences infirmières, cela demeure un énorme défi. En plus de mon travail à temps plein, je pourrais faire un quart de travail la fin de semaine. Mon emploi à temps plein est un temps plein vraiment rempli. Mon salaire de professeure est supérieur à ce qu'il serait dans un milieu clinique, et donc les établissements cliniques ne peuvent pas vraiment se permettre de me payer. Et l'Université s'attend à ce que je travaille à temps plein. Le défi est alors de savoir comment trouver le temps et l'énergie pour s'adonner en plus à la pratique clinique active et rester au fait sur le plan clinique.

Je collabore avec bon nombre d'organisations cliniques, et j'ai des étudiantes en stages cliniques. L'une des attentes dans notre programme de préceptorat est de rencontrer des étudiantes de dernière année et leurs préceptrices dans le milieu clinique, et ce, au moins trois fois par trimestre (au début, au milieu et à la fin). Ce processus nous permet d'avoir une meilleure idée de ce qui se passe dans la pratique clinique. J'essaie de rester informée des enjeux et de suivre les progrès de la pratique clinique, mais cela est très différent de la prestation de soins directs aux patients.

Au cours de mes dix premières années à McMaster, j'ai eu une affectation conjointe (payée à $50 \%$ par le Hamilton Program for Schizophrenia et à $50 \%$ par 
l'université). J'étais dans le milieu clinique avec les étudiantes et je donnais des cours à l'université; mais, j'avais deux bureaux dans des quartiers différents de la ville. Des problèmes au niveau institutionnel ont mené à la disparition des nominations conjointes, qui représentaient des cibles faciles de compressions pour les établissements cliniques.

Je crois vraiment en l'importance des partenariats et de la collaboration (entre le milieu universitaire et le milieu clinique, entre le milieu collégial et le milieu universitaire, entre les programmes et entre les universités) et je pense que nous devons mettre de côté la compétition. Nous sommes toutes en compétition pour du financement, une réalité imbriquée dans le système, mais le travail significatif se réalise dans un environnement collaboratif.

$D^{\text {re }}$ Pepin : En mon nom personnel et au nom de ma corédactrice en chef $\mathrm{D}^{\text {re }}$ Florence Myrick, je vous remercie d'avoir pris le temps de partager vos connaissances, vos réflexions et votre expérience.

\section{References / Références}

Anthony, S. (2011). A feminist poststructural case study of nursing's engagement in interprofessional education. Retrieved from https://macsphere.mcmaster.ca/bitstream/11375/11837/1/fulltext.pdf

Barnett, R. (2009). Knowing and becoming in the higher education curriculum. Studies in Higher Education, 34(4), 429-440.

Benner, P., Sutphen, M., Leonard, V., \& Day, L. (2010). Educating nurses: A call for radical transformation. The Carnegie Foundation for the Advancement of Teaching, San Francisco, CA: Jossey-Bass.

Bevis, E. O., \& Watson, J. (1989). Toward a new curriculum: A new pedagogy for nursing. New York, NY: NLN. 